\title{
STRATEGI POLITICAL MARKETING \\ PASANGAN HM. WARDAN-H. SYAMSUDIN UTI PADA PILKADA KABUPATEN INDRAGIRI HILIR TAHUN 2018
}

\author{
Muhammad Arif \\ Program Studi IImu Komunikasi Universitas Abdurrab \\ Jl. Riau Ujung, No. 73 Pekanbaru, 28292, Indonesia \\ email: muhammad.arif@univrab.ac.id
}

\begin{abstract}
Abstrak
Penelitian ini bertujuan untuk mengetahui strategi pemasaran politik yang dilakukan oleh pasangan HM. Wardan-H. Syamsuddin Uti dalam memenangkan Pemilihan Kepala Daerah (Pilkada) Kabupaten Indragiri Hilir Tahun 2018. Penelitian ini merupakan penelitian deskriptif dengan pendekatan kualitatif. Data yang digunakan adalah data primer dan data sekunder. Data primer hasil penelitian tersebut mewawancarai informan dan observasi yang dilakukan oleh peneliti. Sedangkan data sekunder berupa laporan dan dokumen resmi. Hasilnya menunjukkan bahwa pasangan HM. Wardan-H. Syamsuddin Uti dapat menerapkan strategi pemasaran politik dengan baik. Pemasaran politik pasangan HM. Wardan-H. Syamsuddin Uti lebih progresif dibanding kandidat lainnya. Pasangan HM. Wardan-H. Syamsuddin Uti menggunakan pendekatan pemasaran politik Product Oriented Party (POP). Memfokuskan produknya seperti catatan masa lalu, karakter atau kepribadian yang bisa dilakukan di masa lalu jauh sebelum Pilkada diadakan. Produk semacam itu dipromosikan melalui strategi pemasaran yang lewat dan mendorong pemasaran politik. Pemasaran politik dilakukan dengan cara kunjungan langsung ke desa-desa, rumah-rumah penduduk dan berpartisipasi dalam asosiasi atau organisasi baik formal maupun informal. Sedangkan pemasaran secara politis dilakukan melalui jalur partai politik, tokoh politik, tokoh masyarakat, tokoh agama, dan kelompok organisasi pemuda, organisasi paguyuban, majelis ta'lim yang ikut menjadi relawan atau tim kampanye.
\end{abstract}

Kata kunci: strategi, marketing politik dan pilkada

\begin{abstract}
This study aims to analyze political marketing strategies carried out by HM. Wardan and H. Syamsuddin Uti in winning local election for regional heads of Indragiri Hilir Regency in 2018. This research is descriptive study with qualitative approach. Data used are primary and secondary data. Primary data are from informants and observations, while secondary data are in the form of reports and official documents. The results show that HM. Wardan and $H$. Syamsuddin Uti could implement political marketing strategy very well. Political marketing done by HM. Wardan and H. Syamsuddin Uti is more progressive than the other candidates. HM. Wardan and H. Syamsuddin Uti use political marketing approach to Product Oriented Party (POP) by focusing on products like past records, characters or personalities that could be done before the election was held. Such products are promoted through marketing strategies passing and encouraging political marketing. Political marketing is done by direct visits to villages, people's homes and participating in associations or organizations both formal and informal. Here, political marketing is carried out through political party channels, political figures, community leaders, religious leaders, and groups of youth organizations, community organizations, majelis ta'lim (Islamic learning institutions) participated as volunteers or campaign teams.
\end{abstract}

Keywords: strategy, political marketing and local election 


\section{PENDAHULUAN}

Demokrasi menjadi tren global di negara-negara berkembang. Banyak negaranegara berkembang yang telah menggunakan sistem demokrasi sebagai pedoman dalam ideologinya tidak terkecuali Indonesia. Apalagi selama 32 tahun rezim Orde Baru dan setelah beberapa tahun reformasi bergulir, sentralisasi dan desentralisasi politik di Indonesia telah secara luas mentransformasikan kultur politik elite dalam suatu arah yang demokratis, meskipun masih jauh dari harapan dan kepuasan semua pihak (Usman 2011).

Sebagaimana diatur pada Undang-Undang Nomor 1 Tahun 2015 pasal 1 ayat 1 menyatakan Pemilihan Gubernur dan wakil Gubernur, Bupati dan wakil Bupati, atau Walikota dan Wakil Walikota, selanjutnya disebut pemilihan, adalah pelaksanaan kedaulatan rakyat di wilayah propinsi dan kabupaten/kota untuk memilih gubernur dan wakil gubernur, bupati dan wakil bupati, dan walikota dan wakil walikota secara langsung dan demokratis.

Pemilihan kepala daerah atau yang sering disingkat dengan istilah pilkada, merupakan bentuk praktik demokrasi langsung di level pemerintahan daerah provinsi dan kabupaten/kota. Dalam praktik demokrasi langsung seperti ini yang terpenting dikedepankan adalah proses pemilihan yang memegang teguh tiga aspek penting, yaitu aspek kompetisi antar konstestan, partisipasi dan kebebasan (liberalisasi). Aspek kompetisi berkaitan dengan orang-orang yang mencalonkan diri sebagai kepala daerah dan cara-cara yang dipakai untuk menjadikan mereka ini sebagai calon kepala daerah. Aspek partisipasi berkaitan dengan pemahaman masyarakat terhadap pemilihan kepala daerah, cara mereka merumuskan tipe kepemimpinan kepala daerah dan model mereka membangun kesepakatan politik dengan para calon kepala daerah. Aspek kebebasan erat kaitannya dengan suasana warga pemilih dalam menentukan pilihan politiknya kepada para calon kepala daerah.

Pelaksanaan pilkada dalam konsep demokrasi merupakan prototype pemilu langsung di Indonesia yang diartikan sebagai "pemerintahan dari rakyat, oleh rakyat dan untuk rakyat", dalam konteks implementasi maupun implikasi pilkada ini, bisa dipahami sebagai pengakuan terhadap keanekaragaman, sikap politik partisipatif masyarakat dalam bingkai demokratisasi di tingkat daerah baik pada level provinsi maupun kabupaten/kota. Guna mendukung usaha kandidat dalam mendapatkan 
suara dari masyarakat, setiap kandidat perlu melakukan pendekatan atau strategi yang jitu untuk memenangkan kontestasi dalam pilkada.

Berkaitan dengan uraian di atas, dapat diketahui bahwa sebuah pencapaian harus melalui strategi yang matang, guna tercapainya tujuan yang diinginkan seperti halnya dalam sebuah pilkada. Strategi menjadi hal yang sangat penting dalam upaya memenangkan suara dalam suatu pemilihan. Strategi yang baik merupakan strategi yang tersusun atas dasar perencanaan-perencanaan yang matang dengan pelaksanaan secara efektif dan efisien.

Menurut Firmanzah (2012) salah satu model pendekatan yang relatif baru dalam menjawab fenomena sistem pemilihan langsung (pileg, pilpres, pilkada dan pilkades) adalah pendekatan political marketing. Dengan menerapkan political marketing, maka kampanye yang dilakukan oleh kandidat akan lebih berbobot dengan mempromosikan apa saja ide, gagasan dan program kerja yang telah dirancang. Program kerja merupakan perwujudan nyata dari usaha penyelesaian permasalahan yang ada di tengah masyarakat. Sehingga masyarakat sebagai pemilih dapat melihat bagaimana kapasitas sesungguhnya yang dimiliki oleh kandidat. Political marketing merupakan pendekatan yang efektif untuk bisa membangun hubungan jangka panjang dengan masyarakat sebagai pemilih.

Kabupaten Indragiri Hilir sebagai salah satu kabupaten/kota yang ada di Propinsi Riau yang turut menyelenggarakan pemilihan kepala daerah serentak gelombang ketiga tahun 2018 yang dilaksanakan secara bersamaan dengan pemilihan Kepala Daerah Propinsi Riau. Sembilan kabupaten/kota lainnya di Provinsi Riau yakni; Kabupaten Siak, Kabupaten Pelalawan, Kabupaten Rokan Hulu, Kabupaten Rokan Hilir, Kabupaten Indragiri Hulu, Kabupaten Bengkalis, Kabupaten Kepulauan Meranti, Kabupaten Kuantan Singingi dan Kota Dumai sebelumnya sudah menggelar pilkada serentak gelombang pertama pada Tahun 2015. Pelaksanaan pilkada serentak gelombang kedua pada tahun 2017 juga diikuti 2 Kabupaten/Kota di Provinsi Riau yakni; Kabupaten Kampar dan Kota Pekanbaru.

Memaknai pemasaran politik dalam konteks pilkada yang dilakukan secara ideal, maka partai politik ataupun pasangan calon dapat menyusun strategi-strategi yang berupa product, place, price, dan promotion apa saja yang nantinya yang akan ditawarkan kepada masyarakat luas termasuk program kerja apa yang akan dijalankan apabila terpilih. Melalui pemasaran politik yang ideal, maka akan 
memberikan manfaat bagi partai politik ataupun pasangan calon dalam membangun hubungan dengan pemilih, tentu saja para pasangan calon berharap akan mendapatkan dukungan dari masyarakat dalam bentuk suara pada pilkada yang akan dilaksanakan.

Terdapat bebrapa faktor yang akan mempengaruhi menang atau kalahnya pasangan calon pada suatu event pilkada, baik itu faktor internal yang dalam hal ini adalah partai serta pasangan calon yang diusung, maupun faktor eksternal yaitu masyarakat selaku pemilih. Dalam hal ini perilaku pemilih merupakan hal yang penting untuk diperhatikan oleh masing-masing kandidat karena hal ini akan saling berkaitan dengan bagaimana strategi pemasaran politik (political marketing) yang akan dilakukan oleh masing-masing pasangan calon dengan tujuan tentunya agar dapat memperoleh suara sebanyak mungkin dari pemilih.

Faktor internal merupakan faktor yang cukup mempengaruhi menang atau kalahnya pasangan calon dalam suatu pilkada adalah bagaimana partai serta pasangan calon yang diusung tersebut mampu menarik simpati masyarakat, yaitu dengan melakukan pemasaran politik yang ideal. Sedangkan faktor eksternal juga merupakan hal yang tidak kalah penting untuk diperhatikan oleh suatu partai politik maupun pasangan calon dalam menyampaikan produk politik kepada masyarakat, mengingat masyarakat saat ini sudah semakin cerdas dan kritis, maka perlu adanya kesiapan yang matang dalam menyampaikan program politik pasangan calon agar apa yang disampaikan tersebut dapat membuat masyarakat tertarik dan kemudian memilih pasangan calon yang bersangkutan.

Setiap pasangan calon dalam pilkada di Kabupaten Indragiri Hilir tentunya memiliki strategi pemasaran politik masing-masing. HM. Wardan selaku bupati incumbent Kabupaten Indragiri Hilir dengan didampingi calon wakil bupati H.Syamsuddin Uti mencoba menarik simpatisan untuk kembali memenangkan Pilkada Kabupaten Indragiri Hilir tahun 2018. Bermula pada Pilkada Kabupaten Indragiri Hilir tahun 2013 dengan slogan "SPIRIT BARU" periode pertama masa pemerintahan Bupati H.M. Wardan telah terbukti secara nyata penyelenggaraan kepemimpinan daerah yang menjunjung amanah, membangun negeri (Pekanbarutribunnews.com)

Dalam lima tahun kepemimpinannya pada periode pertama, kepercayaan rakyat terus dibangun dan terkonfirmasi dengan tingkat kepuasan publik yang tinggi 
atas banyaknya prestasi dan pencapaian pembangunan yang sangat positif dapat dilihat, dialami serta dirasakan langsung oleh masyarakat Indragiri Hilir. Pada pilkada serentak 2018 ini H.M. Wardan kembali maju untuk periode kedua masa jabatan 2018-2023, kali ini berpasangan dengan H. Syamsuddin Uti, seorang tokoh masyarakat daerah, pengusaha sukses sekaligus politisi senior yang cukup dikenal di kalangan masyarakat Kabupaten Indragiri Hilir. Adapun Visi 2018-2023 yakni: 'Untuk kejayaan Inhil yang Semakin Maju, Bermarwrah dan Bermartabat' (Visi, Misi Paslon HM. Wardan-H.Syamsuddin Uti 2018)

\section{STUDI LITERATUR}

\section{Strategi}

Dalam Kamus Besar Bahasa Indonesia (2005: 1902) disebutkan bahwa strategi adalah ilmu dan seni menggunakan semua sumber daya bangsa-bangsa untuk melaksanakan kebijakan tertentu dalam situasi perang dan damai, atau rencana yang cermat mengenai kegiatan untuk mencapai sasaran khusus. Effendy (2007: 32) mengatakan bahwa strategi pada hakikatnya adalah perencanaan dan manajemen untuk mencapai tujuan, namun untuk mencapai tujuan tersebut, strategi tidak berfungsi sebagai peta jalan yang memberikan arah saja, melainkan harus mampu menunjukkan bagaimana taktik operasionalnya.

Strategi dalam menghadapi pilkada merupakan perencanaan yang cermat yang disusun dan dilaksanakan oleh tim kampanye yang memiliki tujuan mencapai kemenangan atas sasaran yang ditentukan dalam pilkada. Sasaran merupakan apa yang ingin dicapai oleh kandidat dan tim kampanye dalam hal ini adalah target dukungan pemilihan yang diwujudkan dalam pemberian suara kepada kandidat tersebut. Untuk memahami strategi politik dalam penelitian ini, kita perlu tahu perbedaan strategi dan taktik. Langkah awal saat kita memutuskan apa yang seharusnya kita kerjakan, kita memutuskan sebuah strategi, sedangkan jika memutuskan bagaimana untuk mengerjakan sesuatu, itulah yang disebut taktik.

\section{Political Marketing}

Political Marketing dalam sebuah pemilihan umum (pemilu) memainkan peran yang sangat penting karena merupakan bagian dari aktivitas persuasi dalam pendekatan 
pemasaran politik. Pada dasarnya political marketing menurut Nursal (2004) adalah serangkaian aktivitas terencana, strategis tapi juga taktis. Tujuannya membentuk dan menanamkan harapan, sikap, keyakinan orientasi dan perilaku memilih. Nursal lebih lanjut menjelaskan ada 4 fungsi political marketing sebagai berikut: pertama, analisis sosial pasar, yakni memetakan persepsi dan preferensi para pemilih, baik konstituen maupun non-konsituen, terhadap kontestan-kontestan yang akan bertarung di arena pemilu. Kedua, menetapkan tujuan objektif kampanye, marketing effort dan pengalokasian sumber daya. Ketiga, mengidentifikasi dan mengevaluasi alternatif-alternatif stategi implementasi strategi untuk membidik segmen-segmen tertentu yang disasar berdasarkan sumber daya yang ada. Keempat, memantau dan mengendalikan penerapan strategi untuk mencapai sasaran objektif yang telah ditetapkan.

Menurut Firmanzah (2012), dalam proses political marketing, digunakan penerapan 4P bauran marketing. Pertama, produk (product) berarti partai, kandidat dan gagasan-gagasan partai yang akan disampaikan konstituen. Produk ini berisi konsep, identitas ideologi. Baik dimasa lalu maupun sekarang yang berkontribusi dalam pembentukan sebuah produk politik. Kedua, promosi (promotion) yang mencakup upaya periklanan, kehumasan dan promosi untuk sebuah partai yang dikombinasikan sedemikian rupa sesuai dengan kebutuhan masyarakat. Dalam hal ini, pemilihan media perlu dipertimbangkan.

Ketiga adalah Harga (price) yang mencakup banyak hal, mulai ekonomi, psikologis, sampai citra nasional. Harga ekonomi mencakup semua biaya yang dikeluarkan partai selama periode kampanye. Harga psikologis mengacu pada harga persepsi psikologis misalnya, pemilih merasa nyaman, dengan latar belakang etnis, agama, pendidikan dan lain-lain. Sedangkan harga citra nasional berkaitan dengan apakah pemilih merasa kandidat tersebut dapat memberikan citra positif dan dapat menjadi kebanggaan negara. Keempat adalah penempatan (place), berkaitan erat dengan cara hadir atau distribusi sebuah partai dan kemampuannya dalam berkomunikasi dengan para pemilih. Ini berati sebuah partai harus dapat memetakan struktur serta karakteristik masyarakat, baik itu geografis maupun demografis. 


\section{Pendekatan Political Marketing}

Selanjutnya menurut Marshment dalam Perdana (2012) yaitu: Product Oriented Party (POP), Sales Oriented Party (SOP) dan Market Oriented Party (MOP). Product Oriented Party hanya akan memfokuskan pada dirinya sendiri. Partai yang hanya berorientasi pada produk atau diri mereka sendiri cenderung menolak segala perubahan produk politiknya dan tidak melihat dari sudut pandang masyarakat sebagai pemilih. Resikonya adalah partai semacam ini akan kalah dalam pemilu. Sales Oriented Party mulai memasukkan unsur pemasaran dengan mengadakan satu tahapan riset untuk merancang pesan politik. Tetapi partai jenis ini tidak mengubah perilakunya berdasarkan dengan keingian pemilih, melainkan mencoba mempengaruhi pemilih dengan pesan-pesan membujuk yang sudah dirancang sedemikian rupa seperti dalam iklan. Sedangkan Market Oriented Party melakukan riset awal untuk mengetahui keinginan masyarakat sebagai pemilih diawal sebelum mereka mendesain produk.

\section{Pemilihan Kepala Daerah}

Pemilihan kepala daerah atau yang disingkat dengan pilkada merupakan rekrutmen politik berupa penyeleksian rakyat terhadap tokoh-tokoh yang mencalonkan diri sebagai kepala daerah, baik pada jabatan gubernur/wakil gubernur maupun bupati/wakil bupati atau walikota/ wakil walikota. Kepala daerah adalah jabatan politik atau jabatan publik yang bertugas memimpin birokrasi menggerakkan jalannya roda pemerintahan di daerah. Fungsi-fungsi pemerintahan terbagi menjadi perlindungan, pelayanan publik, dan pembangunan. Kepala daerah menjalankan fungsi pengambilan kebijakan atas ketiga fungsi pemerintahan tersebut. Dalam konteks struktur kekuasaan, Kepala Daerah adalah kepala eksekutif di daerah. Pemilihan Kepala Daerah (PILKADA) diatur dalam perundang-undangan sebagai berikut:

a. Pasal 56 Undang-Undang No. 32 Tahun 2004 tentang Pemerintah Daerah: Kepala Daerah dan Wakil Kepala Daerah dipilih dalam satu pasangan calon yang dilaksanakan secara demokratis berdasarkan asas langsung, umum, bebas, rahasia, jujur dan adil. 
b. Pasal 1 angka 4 Undang-Undang No. 15 Tahun 2011 tentang Penyelenggara Pemilu: Pemilihan Gubernur, Bupati, dan Walikota adalah pemilihan untuk memilih gubernur, bupati, dan walikota secara demokratis dalam Negara Kesatuan Republik Indonesia berdasarkan Pancasila dan Undang-Undang Dasar Negara Republik Indonesia Tahun 1945.

c. Pasal 1 angka 5 Undang-Undang No. 22 Tahun 2014 tentang Pemilihan Gubernur, Bupati, dan Walikota: Pemilihan Gubernur, Bupati, dan Walikota yang selanjutnya disebut Pemilihan adalah pelaksanaan kedaulatan rakyat di provinsi dan kabupaten/kota untuk memilih gubernur, bupati, dan walikota secara demokratis melalui lembaga perwakilan rakyat.

d. Peraturan Pemerintah Pengganti Undang-Undang Nomor 1 Tahun 2014 tentang Pemilihan Gubernur, Bupati dan Walikota.

e. Undang-Undang No. 1 Tahun 2015: Pemilihan Gubernur, Bupati, dan Walikota yang selanjutnya disebut Pemilihan adalah pelaksanaan kedaulatan rakyat di Provinsi dan Kabupaten/Kota untuk memilih Gubernur, Bupati, dan Walikota secara langsung dan demokratis.

f. Pasal 1 ayat (1) Undang-Undang No. 8 Tahun 2015: Pemilihan Gubernur dan Wakil Gubernur, Bupati dan Wakil Bupati, serta Walikota dan Wakil Walikota yang selanjutnya disebut Pemilihan adalah pelaksanaan kedaulatan rakyat di wilayah provinsi dan kabupaten/kota untuk memilih Gubernur dan Wakil Gubernur, Bupati dan Wakil Bupati, serta Walikota dan Wakil Walikota secara langsung dan demokratis.

\section{METODE PENELITIAN}

Penelitian ini menggunakan pendekatan deskriptif kualitatif dengan menggunakan metode studi kasus. Metode ini digunakan untuk melihat strategi political marketing yang dilakunan oleh pasangan HM. Wardan-H. Syamsuddin Uti dalam memenangkan Pilkada Kabupaten Indragiri Hilir Tahun 2018. Teknik pengumpulan data terdiri dari wawancara mendalam (depth interview), studi pustaka dan observasi untuk melengkapi data yang diperlukan. 


\section{PEMBAHASAN}

\section{Gambaran Umum Pilkada Kabupaten Indragiri Hilir Tahun 2018}

Pelaksanaan pilkada serentak merupakan amanah dari Pasal 201 ayat (1) dan ayat (2) Peraturan Pemerintah Pengganti Undang-Undang Nomor 1 Tahun 2014 tentang Pemilihan Gubernur, Bupati dan Walikota. Lalu dalam perkembangannya pemerintah dan DPR telah sepakat untuk mengesahkan Undang-Undang Nomor 1 Tahun 2015 sebagaimana telah diubah melalui Undang-Undang Nomor 8 Tahun 2015 tentang Perubahan atas Undang-Undang Nomor 1 Tahun 2015 tentang penetapan Peraturan Pemerintah Pengganti Undang-Undang Nomor 1 tahun 2014 tentang pemilihan Gubernur, Bupati dan Walikota menjadi Undang-Undang. Pilkada serentak sendiri dilaksanakan untuk megakomodir keinginan masyarakat yang menginginkan pelaksanaan pemilu yang lebih efisien dan hemat dari sisi pendanaan dan pelaksanaannya.

Pilkada serentak tahun 2018 merupakan agenda politik nasional dengan penyelenggaraan pemilihan kepala daerah secara serentak di 171 daerah, meliputi 17 provinsi, 115 kabupaten dan 39 kota yang dilaksanakan pada tanggal 27 Juni 2018. Kabupaten Indragiri Hilir merupakan salah satu kapaten/kota yang ada di Provinsi Riau yang ikut melaksanakan pilkada serentak gelombang ketiga. Pelaksanaan pilkada Bupati/Wakil Bupati Indragiri Hilir serentak tersebut bersamaan dengan pelaksanaan Pilkada Gubernur/Wakil Gubernur Provinsi Riau.

Dalam pelaksanaan pilkada Tahun 2018 di Kabupaten Indragiri Hlir diikuti oleh 3 pasangan calon dengan diusung partai politik sebagaimana dipaparkan pada tabet 1 berikut ini:

Tabel 1

Data Pasangan Calon Bupati/Wakil Bupati

Dalam Pemilihan Kepala Daerah Kabupaten Indragiri Hilir Tahun 2018

\begin{tabular}{|c|l|l|c|}
\hline $\begin{array}{c}\text { No. } \\
\text { Urut }\end{array}$ & \multicolumn{1}{|c|}{ Pasangan Calon } & \multicolumn{1}{|c|}{$\begin{array}{c}\text { Partai } \\
\text { Pendukung }\end{array}$} & $\begin{array}{r}\text { Persentase } \\
\text { Dukungan } \\
\text { Parpol }\end{array}$ \\
\hline 1 & H.Rosman Malomo-Mus Muslyadi & $\begin{array}{l}\text { PDIP, Partai } \\
\text { Nasdem }\end{array}$ & $\begin{array}{r}11 \mathrm{Kursi} \\
(24,44 \%)\end{array}$ \\
\hline 2 & H.M.Ramli Wali-H. Ali Azhar & PBB & 17 Kursi \\
\hline
\end{tabular}




\begin{tabular}{|l|l|l|c|}
\hline & & $\begin{array}{l}\text { Partai Gerindra } \\
\text { dan Partai } \\
\text { Hanura }\end{array}$ & $(37,78 \%)$ \\
\hline \multirow{3}{*}{3} & H.M. Wardan- & $\begin{array}{l}\text { Partai Golkar, } \\
\text { H. Syamsuddin Uti }\end{array}$ & $\begin{array}{l}\text { Partai Demokrat, } \\
\text { PAN dan PKS }\end{array}$ \\
\hline
\end{tabular}

Sumber: data Olahan KPU Kab.Inhil, 2018

Pada tabel 1 diatas dapat dilihat bahwa pasangan calon nomor urut 2 dan 3 sama memperoleh dukungan sebanyak 17 kursi DPRD atau 37,78 persen, sementara pasangan calon noomor urut 1 hanya mendapat dukungan 11 kursi DPRD atau sama dengan 24,44 persen. Sekedar informasi bahwa syarat untuk mencalonkan diri dalam pilkada harus mendapat dukungan 20\% kursi DPRD atau $25 \%$ total suara sah pemilu legislatif (DPRD).

Berdasarkan hasil akhir perhitungan suara pada Pilkada Tahun 2018 Kabupaten Indragiri Hilir, ternyata dari 3 pasangan calon yang mengikuti Pilkada, ternyata pasangan H.M. Wardan dan H. Syamsuddin Uti yang yang memperoleh suara terbanyak dan terpilih kembali sebagai Pasangan Bupati dan Wakil Bupati Indragiri Hilir untuk masa jabatan 2018-2023. HM. Wardan sendiri merupakan petahana yang menjabat Bupati Indragiri Hilir pada periode 2013-2018 yang berpasangan dengan $\mathrm{H}$. Rosman Malomo.

Selanjutnya, adapun asil perolehan suara pilkada Kabupaten Indragiri Hilir Tahun 2018 selanjutnya dapat dilihat pada tabel berikut ini:

Tabel 2

Data perolehan suara Pilkada Kabupaten Indragiri Hilir Tahun 2018

\begin{tabular}{|c|l|c|c|}
\hline No.Urut & \multicolumn{1}{|c|}{ Nama Pasangan Calon } & $\begin{array}{c}\text { Perolehan } \\
\text { Suara }\end{array}$ & Persentase \\
\hline 1 & H.Rosman Malomo-Mus Muslyadi & 60.861 & $23,47 \%$ \\
\hline 2 & H.M.Ramli Walid-H. Ali Azhar & 64.675 & $24,95 \%$ \\
\hline 3 & H.M. Wardan-H. Syamsuddin Uti & 133.719 & $51,58 \%$ \\
\hline \multicolumn{2}{|c|}{ Jumlah Perolehan Suara Sah Pilkada } & $\mathbf{2 5 9 . 2 5 5}$ & \\
\hline
\end{tabular}

Sumber: Data Olahan dari Sekretariat KPU Kab.Inhil Tahun 2018. 
Berdasarkan data pada tabel 2 di atas, dapat diketahui bahwa dalam Pilkada Kabupaten Indragiri Hilir tahun 2018 dimenangkan oleh pasangan nomor urut 3 yakni pasangan H.M. Wardan-H.Syamsuddin Uti yang memperoleh suara sebanyak 133.719 suara atau 51,58 persen, mengungguli 2 pasangan kandidat lainnya. Pasangan nomor urut 2 yakni pasangan H.M.Ramli Walid dan H. Ali Azhar memperoleh 64.675 suara atau 24,95 persen sebagai pasangan yang memperoleh suara terbanyak kedua. Sedangkan pasangan H.Rosman Malomo-Musmulyadi hanya mampu menempati posisi ketiga dengan meraup suara sebesar 60.861 suara atau 23,47 persen.

\section{Analisis Strategi Polical Marketing Pasangan HM. Wardan-H.Syamsuddin Uti Dalam Pilkada Kabupaten Indragiri Hilir Tahun 2018}

Sebagaimana telah dipaparkan dalam tinjauan teoritis, bahwa Strategi political marketing dimulai dari kandidat melakukan empat program utama yaitu; pertama, menciptakan produk politik berupa visi dan misi yang diusung pasangan HM. Wardan-H. Syamsuddin Uti. Kedua, pasangan HM. Wardan dan H. Syamsuddin Uti melakukan promosi atau pendekatan kepada segenap masyarakat Kabupaten Indragiri Hilir. Ketiga, mempertimbangkan price berkaitan seluruh pembiayaan yang dikeluarkan oleh pasangan HM. Wardan-H. Syamsuddin Uti selama mencalonkan diri. Keempat, mempertimbangan place atau tempat, yakni cara hadir pasangan HM. Wardan-H. Syamsuddin Uti dalam melakukan komunikasi-komunikasi politik ditengah masyarakat Kabupaten Indragiri Hilir.

\section{a. Analisis Produk (Product)}

Menurut Firmansyah (2012) produk politik dapat berupa; pertama, party platform (platform partai), kedua, past record (catatan tentang hal-hal yang dilakukan dimasa lampau), dan ketiga, personal characteristic (karakteristik kepribadian). HM. Wardan selaku ketua DPD Partai Golkar Kabupaten Indragiri Hilir yang merupakan partai pemenang kedua pada pileg 2014 dengan jumlah perolehan kursi DPRD sebanyak 8, begitu juga dengan pasangannya $\mathrm{H}$. Syamsuddin Uti merupakan ketua DPC Partai Demokrat Kabupaten Indragiri Hllir yang memperoleh 5 kursi pada pileg 2014, ditambah dukungan partai kualisi lainnya seperti PKS dan PAN serta beberapa partai non-parlemen yang menyatakan 
dukungannya ke pasangan ini, menjadi salah satu sumber energi dalam meraup suara pemilih. Melalui jalur struktur serta simpatisan partai akan mudah mensosialisasikan pasangan calon yang merupakan tokoh politik serta programprogramnya. Selain dukungan yang besar diperoleh dari partai politik, produk utama pasangan HM. Wardan-H. Syamsuddin Uti di bidang party platform adalah visi dan misi yang dirancang sesuai dengan kebutuhan dan permasalahan yang dihadapi oleh masyarakat Kabupaten Indragiri Hilir.

Pada Pilkada Kabupaten Indragiri Hilir tahun 2018, pasangan HM. Wardan-H. Syamsuddin Uti mengusung visi: "Untuk Kejayaan Inhil yang semakin Maju, Bermarwah dan Bermartabat". Visi ini merupakan bentuk konsistensi dan sekaligus sebuah gambaran cita-cita untuk terus bergerak bersama rakyat melanjutkan pembangunan demi kejayaan Kabupaten Indragiri Hilir. Untuk Inhil, hal ini artinya menciptakan kondisi atau keadaan yang mantap, mapan, lebih menguntungkan, lebih berkemaslahatan, lebih membahagiakan dan semakin bermakna positif bagi seluruh warga Kabupaten Indragiri Hilir Provinsi Riau seraya senantiasa mengharapkan ridho dan lindungan Tuhan Yang Maha Esa. Semakin maju berarti melanjutkan pembangunan yang nyata hasiinya dan benarbenar dirasakan manfaatnya baik dalam pembangunan infrastruktur dasar, sarana prasarana, pemberdayaan masyarakat, pertumbuhan ekonomi daerah dan perbaikan kesejahteraan rakyat yang semakin lebih baik, lebih merata dan berkeadilan, di daerah perdesaan maupun di daerah perkotaan, serta kelurahan yang tercakup dalam wilayah kabupaten, sehingga tercapai pembangunan Kabupaten Indragiri Hilir yang lebih berdaya saing positif dan makin diperhitungkan sebagai salah satu barometer pembangunan daerah kabupaten di Indonesia.

Bermarwah mengindikasikan pemimpin dan rakyat Indragiri Hilir terus bergerak bersama, pemerintahannya menjunjung amanah membangun negeri, rakyatnya berpartisipasi membela dan berkarya untuk negeri, bersama-sama dengan spirit yang terus bergelora, berkarya nyata untuk berjaya dan saling jaga menjaga kebanggaan positif pada daerahnya, Kabupaten Indraglri Hilir tercinta. Bermartabat artinya penyelenggaraan pemerintahan dan pembangunan daerah yang manusiawi dan berkeadilan sosial yang ditujukan untuk sebesar-besarnya kepentingan dan kemaslahatan rakyat Indragiri Hilir, pelayanan publik yang 
responsif, berdemokrasi secara sehat, tidak ada diskriminasi, rakyatnya hidup rukun, tentram dan berbahagia dalam ridho dan lindungan Tuhan Yang Maha Kuasa (KPU Kab.Inhil Tahun 2018).

Untuk mewujudkan visinya, pasangan HM. Wardan-H. Syamsuddin Uti menyusun langkah-langkah atau yang lazim disebut misi sebagai operasionalisasi dari visi. Adapun misi tersebut antara lain:

1) Memantapkan tata kelola kepemerintahan yang makin responsif, partisipatif, inovatif, efektif dan berketaatan hukum didukung kualitas Sumber Daya Manusia aparatur yang menjunjung amanah dan sistem manajemen organisasi birokrasi pemerintahan daerah yang semakin maju untuk menghasilkan pelayanan publik yang lebih bermutu dalam membangun negeri.

2) Memantapkan pemetaan pembangunan infrastruktur dasar, di daerah perdesaan maupun perkotaan, di desa maupun kelurahan, di berbagai penjuru dan wilayah kabupaten.

3) Melanjutkan pengoptimalan pengelolaan Sumber Daya Alam dan lingkungan secara berkelanjutan, meliputi pemantapan aktivitas rakyat dalam menghasilkan produk-produk unggulan daerah di bidang pertanian, perkebunan, perikanan, perternakan dan berbagai karya kreatif-lokal sesuai potensl dan keadaan setempat.

4) Memantapkan pembangunan Sumber Daya Manusia yang semakin berkualitas dan berdaya saing tawakal, sehat, berakhlak mulia, handal dan unggul melalui penguatan pelayanan pendidikan yang lebih baik lagi (sekolah umum maupun agama, sekolah negeri maupun swasta, muatan pendidikan agama dan pendidikan karakter, termasuk pendidikan nonformal, literasi dan keterampilan-keahlian).

5) Memantapkan pelayanan kesehatan masyarakat melalui peningkatan pembangunan infrastruktur dasar kesehatan, peningkatan kesehatan lingkungan dan berbagai perbaikan mutu pelayanan pasien rawat jalan maupun pasien rawat inap, serta peningkatan Sumber Daya Manusia aparatur dan tenaga medis di Pustu, Puskesmas hingga RSUD.

6) Memantapkan peningkatan partisipasi sosial dan pemberdayaan masyarakat dengan spirit dan sinergi peran serta berbagai kelompok sosial 
kemasyarakatan, pemuda dan kaum perempuan serta pemanfaatan nilai kearifan lokal dan kegotong-royongan, termasuk dengan menggalang kemitraan dengan dunia usaha/korporasi dalam pembangunan.

7) Memantapkan pembangunan kerukunan, keamanan, ketertiban dan ketentraman kehidupan sosial antar warga yang saling menghormati persamaan dan perbedaan, serta bersama-sama terus saling menjaga marwah dan martabat daerah Indragiri Hilir.

8) Melanjutkan upaya menurunkan tingkat kemiskinan dan pengangguran melalui pemantapan pembangunan ekonomi rakyat yang meliputi UMKM pertanian, perkebunan, perikanan, perternakan, kerajinan rumahtangga, ekonomi kreatif dan pariwisata.

9) Memantapkan peningkatan pertumbuhan dan daya saing ekonomi daerah dengan membuka ruang yang transparan dan akuntabel terhadap masuknya investasi dunia usaha skala besar yang pro-rakyat, mengendalikan inflasi; dan lebih optimal dalam pengelolaan anggaran maupun asset daerah. Dan

10) Memantapkan prioritisasi program percepatan pembangunan khusus dalam rangka menggelorakan pembangunan daerah untuk kejayaan Indragiri Hilir yang semakin maju, bermarwah dan bermartabat.

Past Record dan Personal Characteristics yang merupakan catatan kebaikan yang dilakukan dimasa lampau. Sebagaimana diketahui bahwa HM.Wardan merupakan bupati incumbent yang dalam periode pertama kepemimpinannya telah mampu menorehkan berbagai perestasi seperti program Desa Maju Inhil Jaya, Program Magrib Mengaji, Program Revitalisasi perkebunan masyarakat, selain itu HM. Wardan juga tercatat sebagai pribadi yang religius sering menjadi khatib dan imam disela-sela kunjungannya ke masyarakat baik dalam urusan kedinasan maupun urusan pribadi, beliau juga merupakan cucu Tokoh agama yang tersohor di Kabupaten Indragiri Hilir yankni KH. Abdul Rahman Ya'kub (pendiri Pondok Pesantren Nurul Wathan Desa Pasar Kembang Kecamatan Keritang).

Selain Past Record dan Personal Characteristics yang baik dari HM. Wardan, kehadiran H. Sayamsuddin Uti selaku pendampingnya (wakil bupati) semakin menambah energi positif bagi pasangan ini. Meskipun pada pilkada 
sebelumnya tahun $2013 \mathrm{H}$. Syamsuddin Uti dan H. Muslimin Mabbate merupakan lawan politik HM. Wardan yang ketika itu berpasangan dengan H.Rosman Malomo, namun dengan bergabuangnya dwi tunggal birokrat dan pengusaha menjadikan pasangan ini semakin kuat dan akhirnya menjadi pemenang. Sosok H. Samsuddin Uti bagi masyarakat Indragiri Hilir selain sebagai sosok pengusaha sukses, juga merupakan sosok politikus kawakan yang memiliki pengalaman malang melintang di dunia perpolitikan. Meskipun pada pilkada sebelumnya $\mathrm{H}$. Syamsuddin Uti merupakan rival dari HM. Wardan, namun kedua tokoh ini memiliki arah dan tujuan yang sama demi kejayaan Indragiri Hilir, menjadikan faktor utama $H$. syamsuddin Uti yakin untuk mendampingi HM. Wardan. Dikenal sebagai tokoh, politikus dan pengusaha sukses yang sudah sangat dikenal oleh masyarakat Indragiri Hilir, membuat pasangan ini memang semakin ideal.

\section{b. Analisis Promosi (Promotion)}

Terdapat dua starategi yang dilakukan oleh pasangan HM. WardanH.Syamsuddin Uti dalam upaya mempromosikan dirinya sebagai calon bupati dan wakil bupati Indragiri Hilir, yaitu strategi pemasaran produk politik secara langsung kepada calon pemilih (push political marketing) dan strategi pemasaran melalui kelompok, tokoh masyarakat yang memiliki pengaruh di masyarakat (pass political marketing).

Push political marketing dilakukan oleh pasangan HM. Wardan-H. Syamsuddin Uti dengan cara rutin melakukan kunjungan ke desa-desa, ke rumah-rumah masyarakat baik yang sifatnya urusan kedinasan (bupati), keinginan pribadi untuk melakukan silaturrahim maupun atas dasar undangan warga masyarakat. HM. Wardan dengan berbekal multi talenta yang dimilikinya, baik sebagai sosok bupati, tokoh pendidikan maupun sebagai tokoh agama menjadikan jalan bagi HM. Wardan mudah dikenal di tengah-tengah masyarakat, tidak jarang pada kesempatan-kesempatan seperti ini beliau sampaikan visi dan misinya tentang bagaimana idealnya dalam membangun Indragiri Hilir kedepan. Hal yang sama juga dilakukan oleh H.Syamsuddin Uti, beliau terkenal sebagai pengusaha yang dermawan, low profile dan juga aktif turun menemui masyarakat baik inisiatif pribadi maupun memenuhi undangan masyarakat. Sedangkan pass 
political marketing dilakukan oleh pasangan HM. Wardan-H. Syamsuddin Uti, selain jalur tim sukses yang resmi dari partai politik pengusunga, juga dibentuk relawan-relawan yang meskipun tidak dibentuk secara resmi sebagai tim sukses pemenangannya, namuan beberapa tokoh masyarakat, perkumpulan majelis taklim, organisasi pemuda dan organisasi paguyuban secara sukarela ikut membatu dalam mensosialisasikan visi, misi serta program kerja yang diusung oleh pasangan HM. Wardan-H. Syamsuddin Uti.

\section{c. Analisis Tempat (Place)}

Bedasarkan analisa promosi diatas, selanjutnya dapat dilihat bahwa cara hadir pasangan HM. Wardan-H. Syamsuddin Uti dilakukan baik secara langsung face to face melalui kunjungan-kunjungan langsung ke desa-desa dan aktif mengunjungi rumah-rumah masyarakat dan ikut serta dalam kegiatan baik formal maupun informal. Berbeda dengan kandidat lainnya yang mengandalkan kerja tim sukses. pasangan HM. Wardan-H. Syamsuddin Uti melakukan persiapan lebih matang jauh sebelum pelaksanaan Pilkades, selain itu kandidat ini juga sudah melakukan segmentasi pemilih. Segmentasi ini didasarkan pada segmen tingkat pendidikan, pekerjaan, umur, jenis kelamin dan fakor kesukuan.

\section{d. Analisis Harga (Price)}

Harga (price) adalah mencakup banyak hal, mulai ekonomi, psikologis, sampai citra kandidat ditengah masyarakat. Terkait harga dari segi ekonomi pasangan HM. Wardan-H.Syamsuddin selain memiliki dukungan partai politik besar yang bisa diandalkan, karena keduanya merupakan ketua atau pimpinan partai politik, begitu juga bila dilihat dari segi pemodal dari tim suskses-pun banyak relawanrelawan melakukan penggalangan dana tim pemenangan disamping sosok $\mathrm{H}$. Samsuddin Uti sendiri merupakan pengusaha yang sukses. Begitupun jika harga dilihat dari aspek psikologis dan citra kandidat pasangan HM. WardanH.Syamsuddin Uti mengungguli kandidat lainnya, dengan berbekal pergaulan yang baik di tengah masyarakat, citra diri sebagai sosok perpaduan anatara birokrat dengan pengusaha membuat masyarakat memberikan dukungannya kepada pasangan HM. Wardan-H.Syamsuddin Uti. 


\section{KESIMPULAN}

Strategi Political Marketing yang dilakukan pasangan HM. Wardan-H.Syamsuddin Uti dalam Pilkada Kabupaten Indragiri Hilir Tahun 2018 dengan menerapkan pendekatan 4P, yakni Produk (product), Promosi (promotion), Penempatan (place) dan Harga (price) telah terbukti dan mampu diterapkanya dengan baik dan hasilnya pasangan HM. Wardan-H.Syamsuddin Uti mendapatkan suara terbanyak dan terpilih menjadi Bupati dan Wakil Bupati Indragiri Hilir periode 2018-2023.

Keunggulan pendekatan Product Oriented Party (POP), pasangan HM. Wardan-H.Syamsuddin Uti memfokuskan produk yang dimilikinya seperti Past Record, berupa karakter atau kepribadian yang baik yang dilakukan di masa lampau jauh sebelum pilkada digelar. Produk tersebut dipromosikan melalui strategi pemasaran pass dan push political marketing. Pass political marketing dilakukan dengan cara kunjungan langsung desa-desa, ke rumah-rumah masyarakat dan ikut serta dalam berbagai undangan masyarakat baik yang sifatnya formil maupun nonformil, sedangkan push political marketing dilakukan melalui tokoh-tokoh politik, tokoh-tokoh masyarakat, tokoh-tokoh agama, tokoh-tokoh paguyuban, tokoh organisasi pemuda serta perkumpulan majelis-majelis taklim yang menjadi sebagai tim suksesnya.

Sedangkan market oriented party, pasangan HM. Wardan-H.Syamsuddin Uti melakukan riset awal untuk mengetahui persepsi dan keinginan masyarakat sebagai pemilih diawal terhadap dirinya serta harapan-harapan bagi bupati/wakil bupati yang akan datang, selain itu juga melakukan pengamatan terhadap keluhan-keluhan masyarakat pada kebijakan-kebijakan bupati/wakil bupati sebelumnya yang dianggap tidak pro-rakyat. Hal ini oleh pasangan HM. Wardan-H.Syamsuddin Uti merasa penting untuk dilakukan dalam rangka mendesain produk politik.

\section{REFERENSI}

Effendy, Onong Uchjana. 2007. Dinamika Komunikasi. Bandung: Remaja Rosdakarya

Firmanzah, 2012. Marketing Politik. Jakarta: Yayasan Obor Indonesia. 
Nursal, Adman, 2004. Political Marketing : Strategi Memenangkan Pemilihan Umum, Jakarta, Gramedia Pustaka Utama

Perdana, Inco Hary. 2012. Tesis. "Political Marketing Partai Politik Baru Menuju Pemilu 2014 Studi Kasus Strategi Pemenangan Partai Nasdem". Jakarta: Universitas Indonesia

Pusat Bahasa Departemen Pendidikan Nasional RI, 2005 Kamus Besar Bahasa Indonesia, Jakarta Balai Pustaka

Usman, J. (2011). Implementasi Kebijakan Tata Kelola Pemerintahan Daerah Dengan Semangat Euforia Demokrasi Lokal. Otoritas: Jurnal IImu Pemerintahan, 1(1).

Undang Undang Nomor 32 Tahun 2004 tentang Pemerintah Daerah

Undang Undang Nomor 15 Tahun 2011 tentang Penyelenggara Pemilu

Undang-Undang Nomor 22 Tahun 2014 tentang Pemilihan Gubernur, Bupati, dan Walikota

Undang-Undang Nomor 1 Tahun 2015 tentang Penetapan Peraturan Pemerintah Pengganti Undang-Undang Nomor 1 Tahun 2014 Tentang Pemilihan Gubernur, Bupati, Dan Walikota Menjadi Undang-Undang

Undang-undang Nomor 8 tahun 2015 tentang perubahan atas undang-undang nomor 1 tahun 2015 tentang penetapan peraturan pemerintah pengganti undang-undang nomor 1 tahun 2014 tentang pemilihan gubernur, bupati, dan walikota menjadi undang-undang

Peraturan Pemerintah Pengganti Undang-Undang Nomor 1 Tahun 2014 tentang pemilihan Gubernur, Bupati dan Walikota

Sudah Dirumuskan Pasangan War dan Su Siapkan 9 Program Unggulan di Pilkada Inhil 2018. Diakses dari http://pekanbaru.tribunnews.com/2018/03/09/sudahdirumuskanpasangan-war-dan-su-siapkan-9-program-unggulan-di-pilkadainhil-2018?page=2, diakses tanggal 1 maret 2019 pukul 16.32

Kisah HM. Wardan dan Syamsuddin Uti dari Indragiri Hilir terpilih menjadi Bupati dan Wakil Bupati. Diakses dari http;//pekanbarutribunnews.com/amp/2018/11/22/kisah-hm-wardan-dansyamsuddin-uti-dari-indragiri-hilir-terpilih-menjadi-bupati-dan-wakilbupati?page=3, diakses tanggal 1 maret 2019 pukul 16.00 
Pemungutan Suara Pilkada 2018 Direncanakan 27 Juni 2018. Diakses dari http://kpu.go.id/index.php/post/r ead/2017/5979/PemungutanSuara-Pilkada2018Direncanakan-27-Juni-2018 pada Sabtu, 20 Mei 2017 Jam 11.08 WIB KPU Kabupaten Indragiri Hilir "Visi, Misi Calon Bupati dan Wakil Bupati Indragiri Hilir Dalam Pemilihan Kepala Daerah Tahun 2018 "

KPU Kabupaten Indragiri Hilir Sertifikat Rekapitulasi Perhitungan Suara Dari Setiap Kecamatan di Tingkat Kabupaten/Kota Dalam Pemilihan Bupati dan Wakil Bupati/ Walikota dan Wakil Walikota Tahun 2018. 